\section{Part 1: Sociodemographic Aspects of Migration}

\section{The Role of Migration in the Composition of the Russian Population}

The global crisis of the late 1980 s and early 1990s has affected all of Russian society including its migration processes. The general instability, the erection of boundaries within a once-unified country, the introduction of visa regulations, and the existence of numerous "hot spots" has led to a decrease in the overall rate of migration. Thus several indicators of migration flows-the number of arrivals in the country, the number of departures from the country, and the number of internal migrants-fell between 1986 and 1992 (see Table 1). In 1992, the number of migrants per 1,000 Russians was 11 percent less than in 1991 and one-third less than in the period 19861990.

\begin{tabular}{|c|c|c|c|}
\hline Year & rrivals & Departures & $\begin{array}{r}\text { Internal } \\
\text { Migrants }\end{array}$ \\
\hline 1986 & 6,400 & 6,100 & 5,500 \\
\hline 1989 & 5,600 & 5,500 & 4,800 \\
\hline 1990 & 5,200 & 5,000 & 4,200 \\
\hline 1991 & 4,600 & 4,500 & 3,800 \\
\hline 1992 & 4,200 & 4,000 & 3,200 \\
\hline
\end{tabular}

Source: State Statistics Committee of the Russian Federation.

This decline is perhaps surprising given the country's cataclysmic state. But the plain fact is that Russia does not suffer from a migratory avalanche, notwithstanding occasional media claims to the contrary. It is true, however, that contemporary migration in Russia has altered in character due to the country's high level of social, political and economic instability.

For a long time, migration between Russia, on the one hand, and the "near abroad" 1 and foreign countries, on the other hand, did not greatly influence the size of the Russian population. Natural increase (the surplus of births over deaths) was the main factor contributing to population growth. Thus the number of arrivals in the Russian Federation exceeded departures beginning in the mid-1970s. In the period 1979-88, the population grew at an average rate of 180,000 people per year. In any given year, no more than 19 percent of this growth was attributable to positive net migration (a surplus of arrivals over departures).

Over the past few years, however, the contribution of migration to population growth has increased dramati- cally. This is due to a declining birth rate and a rising death rate. By 1992, net migration was unable to compensate for losses caused by the natural decrease of the population. Thus in 1992, for the first time in the post-World War II period, the size of the Russian population actually fell (see Table 2).

\section{Inter-Regional Migration Streams and Changes in Their Direction}

In the last few years, the direction of internal migration has changed substantially. Table 2 indicates that the historical rural-to-urban population flow has been reversed. Most regions in Russia experienced net urban-torural migration in 1992 for the first time in many years. Some 80,000 more people arrived in rural regions than departed from them. ${ }^{2}$

The reasons for this reversal are complex and diverse. They include: fewer urban job opportunities as a result of the general decline of production, the deterioration of many of the social advantages of urban living, and worsening ecological conditions in the cities.

Changes have also taken place in the direction of inter-regional migration. During the Soviet period migrants from all over the Soviet Union were drawn to the North, Siberia and the Far East. But the early 1990 s have wit-
Table 3 Inter-Regional Migration in Russia (in '000s) Annual Average

$$
\text { for 1979-88 }
$$

1990 1991 1992

Economic districts:

Northern

3.9

4.3

$-13.2$

$-24.5$

$-39.2$

$-28.6$

$-45.6$

Far Eastem

33.4

$-9.6$

$-66.1$

$\begin{array}{cccc}\text { Total Siberia and Far East } & 119.1 & -36.3 & -126.7 \\ \text { Source: State Statistics Committee of the Russian Federation. }\end{array}$
$-36.2$

$-150.4$

$-194.8$ nessed a massive flow of people from these regions (see Table 3 ).

In 1992, in the Nenetski and YamaloNenetski regions of Russia, a survey was conducted by the Demographic Centre of the Russian Academy of Science. It demonstrated that 50 percent of the population not native to these places were going to leave. ${ }^{3}$ Threequarters of these people expressed the intention to return to other regions of Russia and one-quarter planned to leave for the near abroad (Ukraine, Belarus, etc.). These people probably originally came from the regions to which they were then planning to return.

(C) I. Orlova, Y. Streltsova, E. Skvortsova, 1994. This open-access work is licensed under a Creative Commons Attribution-NonCommercial 4.0 International License, which permits use, reproduction and distribution in any medium for non-commercial purposes, provided the original author(s) are credited and the original publication in Refuge: Canada's Journal on Refugees is cited. 